\title{
MiR-I 26 Regulates Proliferation and Invasion in the Bladder Cancer BLS Cell Line by Targeting the PIK3R2-Mediated PI3K/Akt Signaling Pathway [Retraction]
}

Xiao J, Lin H, Zhu Y, Zhu Y, Chen L. Onco Targets Ther. 2016;9:5181-5193.

The Editor and Publisher of OncoTargets and Therapy wish to retract the published article. It came to our attention that several figures within the paper appeared to be duplicated, specifically:

- Figure 4A panels Noninfected and BLS-Lv-vector appear to be duplicated with images from Figure 3B panels Control and NC from Wang et al: MicroRNA-200b inhibits pituitary tumor cell proliferation and invasion by targeting PKC $\alpha$ (https://doi. org/10.3892/etm.2017.4681).

- Figure 4A panel BLS-Lv-miR126 appears to be duplicated with an image from Figure 3B panel Mimics from Wang et al: MicroRNA-200b inhibits pituitary tumor cell proliferation and invasion by targeting $\mathrm{PKC} \alpha$ (https://doi.org/10.3892/etm.2017.4681).
- Figure $8 \mathrm{~A}$, the two right panels appear to be duplicated.

- Figure 8B, the two left panels and the far right panel appear to be duplicated.

We attempted to contact the authors of this article but despite multiple attempts received no response. The Editor has determined the findings of the study are no longer valid and requested for the article to be retracted.

Our decision-making was informed by our policy on publishing ethics and integrity and the COPE guidelines on retraction.

The retracted article will remain online to maintain the scholarly record, but it will be digitally watermarked on each page as "Retracted".

\section{Publish your work in this journal}

OncoTargets and Therapy is an international, peer-reviewed, open access journal focusing on the pathological basis of all cancers, potential targets for therapy and treatment protocols employed to improve the management of cancer patients. The journal also focuses on the impact of management programs and new therapeutic agents and protocols on patient perspectives such as quality of life, adherence and satisfaction. The manuscript management system is completely online and includes a very quick and fair peer-review system, which is all easy to use. Visit http://www.dovepress.com/ testimonials.php to read real quotes from published authors. 